\title{
THE RECENT AND FOSSIL MOLLUSKS OF THE GENUS DISASTOMA FROM THE WEST COAST OF AMERICA.
}

\author{
By Paul Bartsch. \\ Assistant Curator, Division of Mollusks, U. S. National Museum.
}

Of this genus only a single species has been reported from the west coast of America, Bittium fastigiatum Carpenter. This was tersely diagnosed by Dr. P. P. Carpenter in his report on the Mollusks of the West Coast of America, made to the British Association for the Advancement of Science in 1863, and published in their report on page 655 in 1864. Later, in 1865, it was more fully described in the Annals and Magazine of Natural History, page 181. This species was collected by Col. E. Jewett in the Lower Pleistocene deposits at Santa Barbara, California.

To this I now add three additional species, Diastoma chrysalloidea Bartsch, from the Gulf of California; Diastoma oldroydæ Bartsch, from San Pedro, California, and Diastoma stearnsi Bartsch, from San Diego, California. $^{a}$

\section{DIASTOMA FASTIGIATA Carpenter.}

Bittium fastigiatum Carpenter, Rep. Brit. Ass. Adv. Sci. for 1863, 1864, p. 655; Ann. Mag. Nat. Hist., ser. 3, vol. 15, 1865, p. 181.

Shell elongate-conic, yellowish white. Nuclear whorls two, well rounded, smooth. Post-nuclear whorls flattened, much wider at the periphery than at the summit, overhanging, ornamented on the first seven whorls by four equal and equally spaced spiral cords, of which the posterior is at the summit and the anterior at some little distance

$a$ In the preparation of the present diagnoses the following terminology is used:

"Axial sculpture," the markings which extend from the summit of the whorls toward the umbilicus.

The axial sculpture may be-

"Vertical," when the markings are in general parallelism with the axis of the shell.

"Protractive," when the markings slant forward from the preceding suture.

"Retractive," when the markings slant backward from the suture.

"Spiral sculpture," the markings following the directions of the coils of the whorls. 
above the suture; on the last whorl an additional slender cord appears between that on the summit and its neighbor. In addition to these spiral cords, the whorls are marked by strong, broad, low, axial ribs, of which twelve occur upon the first and second, fourteen upon the third and fourth, and sixteen upon each of the remaining whorls. The intersections of the spiral cords and

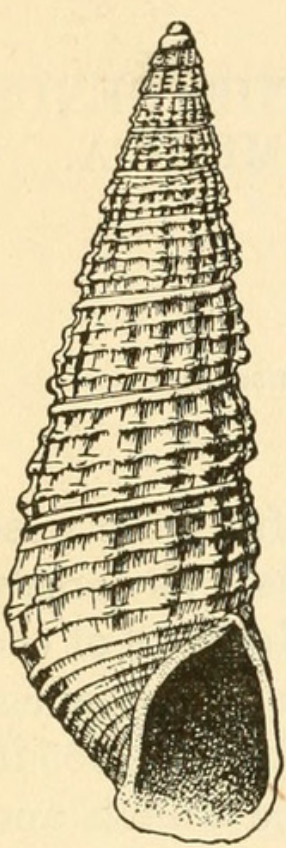

Fig. 1.-Diastoma FASTIGIATA CARPENTER. axial ribs are nodulose. In addition to these cords and ribs, the entire surface of the shell is marked by numerous, very fine, spiral striations and slender lines of growth. Periphery of the last whorl marked by a sulcus which is as wide as the space between the cords on the spire and is crossed by the slender continuations of the axial ribs. Base well rounded, marked by eight equal and subequally spaced, rounded, spiral cords. Aperture elongate, decidedly effuse at the junction of the outer and basal lips, channeled anteriorly and subchanneled at the posterior angle; outer lip thin, rendered somewhat sinuous by the external sculpture; columella short and twisted; parietal wall covered with a thick callus, which extends over the edge of the columella and renders the peritreme complete. In the two specimens before me a strong varix is present a fourth of a turn behind the lip.

The description and figure are based upon two specimens (Cat. No. 162561, U.S.N.M.) collected by Colonel Jewett in the Lower Pleistocene beds at Santa Barbara, California. One, a young individual of eight post-nuclear whorls, has furnished the description of the nucleus. The other, which has lost the nucleus and probably the first postnuclear whorl, having eight post-nuclear whorls remaining, has furnished the remainder of the description. The two specimens mentioned measure: Length, $4.7 \mathrm{~mm}$.; diameter, $1.5 \mathrm{~mm}$.; and length, 6.5 $\mathrm{mm}$.; diameter $2.1 \mathrm{~mm}$., respectively.

\section{DIASTOMA CHRYSALLOIDEA, new species.}

Shell elongate-conic, pinkish white. Nuclear whorls partly decollated, the one remaining, smooth. Post-nuclear whorls appressed at the summit, sloping evenly from the posterior three-quarters between the sutures posteriorly, falling off rapidly between the sutures on the anterior fourth; marked by broad, low, rounded, distinct axial ribs, of which sixteen occur upon all the whorls. In addition to these ribs the whorls are marked by spiral bands, which are about as wide as the spaces that separate them. Of these bands, four occur upon the second turn; the fourth, marking the anterior termination of the sloping shoulder, is a little stronger than the rest and a little wider spaced. 
The same number and disposition of bands occurs upon the third turn, but here the first subperipheral band becomes apparent in the suture. This arrangement holds good on the next turn. On the fifth postnuclear whorl an additional slender cord appears between the first and second and another between the second and third cords, which on the penultimate turn assume the strength of the adjacent members. The intersections of the spiral cords and the axial ribs form illdefined tubercles. Sutures strongly impressed; periphery and base of the last whorl well rounded, the latter marked by seven equal and equally spaced, low, spiral cords, which are almost as wide as the spaces that separate them. In the intervening grooves many slender, axial threads are present. Aperture irregularly ovate, large, decidedly expanded at the junction of the outer and basal lips, channeled anteriorly; posterior angle acute; outer lip thin at the edge where the spiral cords appear as brown spots on a yellowish, white background; columella short, moderately strong; appressed to and reflected over the attenuated base; parietal wall covered with a very thick callus which merges into

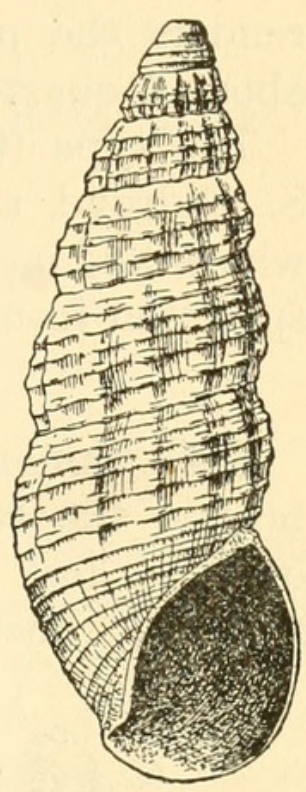

Fig. 2.-DiAstoma CHRYSALLOIDEA BARTSCH. the columellar edge and renders the peritreme complete. A strong varix is present about one-fourth of a turn behind the aperture.

The type (Cat. No. 73996, U.S.N.M.) has seven post-nuclear whorls and measures: Length, $6.3 \mathrm{~mm}$; diameter, $2.4 \mathrm{~mm}$. It comes from the Gulf of Califorina.

DIASTOMA OLDROYDE, new species.

Shell broadly conic, light brown. Nuclear whorls decollated, postnuclear whorls slightly rounded, shouldered at the summit, marked by weak, axial ribs, of which sixteen occur upon the fourth and fifth, eighteen upon the sixth and the penultimate turn. Intercostal spaces about twice as wide as the ribs. In addition to the axial ribs the whorls are crossed by four slender, poorly developed. spiral cords, the intersection of which, with the ribs, renders them feebly nodulose. On the last whorl a slender, additional thread appears between the cord at the summit and the one adjacent to it. The spaces inclosed between the ribs and the spiral cords are rectangular, depressed areas, having their long axes parallel with their spiral sculpture. Periphery of the last whorl marked by a shallow sulcus. Base mod-

Fig. 3.-DiastoMA OLDROYDE BARTSCH. erately long, well rounded, marked by six equal and equally spaced, spiral cords, the axial sculpture being represented by incre- 
mental lines only. Sutures channeled. Aperture irregular, large, decidedly channeled and somewhat twisted anteriorly; posterior angle obtuse; outer lip moderately thin, showing the external sculpture within by transmitted light; columella very strongly curved and revolute; parietal wall covered with a thick callus which renders the peritreme complete. A strong, white varix is present about a quarter turn behind the lip.

The type (Cat. No. 213024, U.S.N.M.) was collected by Mrs. T. S. Oldroyd at San Pedro, California. It has eight postnuclear whorls and measures: Length, $3.8 \mathrm{~mm}$.; diameter, $1.6 \mathrm{~mm}$. Another specimen from the same locality is in Mrs. Oldroyd's collection.

\section{DIASTOMA STEARNSI, new species.}

Shell elongate-conic. Early whorls and columella light chestnut brown, the remaining creamy white. Nuclear whorls decollated, only the last two volutions remaining, which are well rounded and smooth. Postnuclear whorls strongly rounded, marked by low, well-

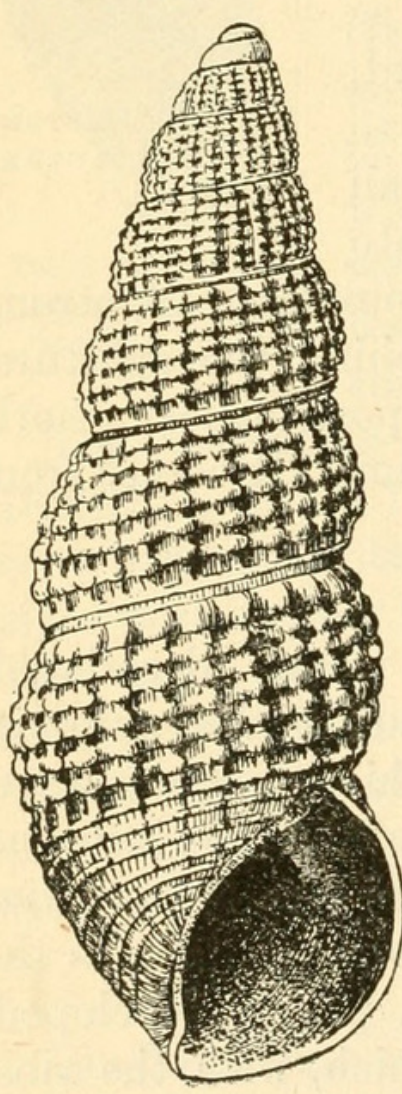

FIg. 4.-D I A S T O M A STEARNSI BARTSCH. rounded, vertical axial ribs which are about as wide as the intercostal spaces; of these ribs sixteen occur upon the first, and twenty-four upon the remaining whorls. In addition to these ribs, the whorls are marked by seven spiral cords, which are about as wide as the spaces that separate them and render the axial ribs nodulose. The cord at the summit is a little wider than the rest, likewise the space that separates it from the adjacent cord and this renders the summit of the whorls crenulated. The first subperipheral cord is apparent on all the whorls and forms the seventh one, between the sutures. The axial ribs usually encroach upon this only feebly, the nodulations therefore being less marked than on the spiral cords posterior to it. Sutures strongly constricted; periphery of the last whorl and base well rounded, the latter marked by six equal and equally spaced spiral cords which are a little less wide than the spaces that separate them. Aperture not quite complete in our specimen, broadly ovate, channeled anteriorly; posterior angle acute; outer lip thin, showing the external markings within; columella moderately strong, somewhat twisted, curved, decidedly reflected; parietal wall glazed with a thick callus.

The type (Cat. No. 32212, U.S.N.M.) has seven postnuclear whorls and measures: Length, $9 \mathrm{~mm}$; diameter, $3 \mathrm{~mm}$. It comes from San Diego and is named for the late Dr. R. E. C. Stearns. 


\section{$2 \mathrm{BHL}$ Biodiversity Heritage Library}

Bartsch, Paul. 1911. "The Recent and fossil mollusks of the genus Diastoma from the west coast of America." Proceedings of the United States National Museum 39(1802), 581-584. https://doi.org/10.5479/si.00963801.39-1802.581.

View This Item Online: https://www.biodiversitylibrary.org/item/53443

DOI: https://doi.org/10.5479/si.00963801.39-1802.581

Permalink: https://www.biodiversitylibrary.org/partpdf/51994

\section{Holding Institution}

Smithsonian Libraries

\section{Sponsored by}

Smithsonian

\section{Copyright \& Reuse}

Copyright Status: Public domain. The BHL considers that this work is no longer under copyright protection.

This document was created from content at the Biodiversity Heritage Library, the world's largest open access digital library for biodiversity literature and archives. Visit BHL at https://www.biodiversitylibrary.org. 